\title{
Toddler Democracy and a Typical Governance in Guinea-Bissau
}

\author{
IAIA TURE, PhD Candidate \\ School of Public Administration and Policy \\ Renmin University of China, China
}

Received: Feb. 18, 2018 Accepted: Mar. 28, 2018 Online published: Mar. 31, 2018

doi:10.5296/jpag.v8i1.12938ＵRL: https://doi.org/10.5296/jpag.v8i1.12938

\begin{abstract}
This paper evolves from the beginning of the democratization process which culminated with the formation of political parties and analyzed the functioning of political parties by observing the practice on democracy and governance system in much more contextualized and corresponding terms from 1991 to 2017. The paper explores the relationships between the political system and the constitution as against the transgression of constitutional power as source of conflicts. The paper also examined carefully the roles of political parties, the media and civil society in democratization process. The paper found that there are inversion of values and mis-concept of democracy, political leaders deviate from key democratic principles and there is a group of political elites addicted to power that have been resorting the political fraud to control power which is complicating democratic progress. In order to forestall the ugly trend, the paper recommends that political leaders and elites should lead the country with wisdom. Elected leaders should be people who are ready to fight tirelessly and positively contribute to building and developing society.
\end{abstract}

Keywords: democracy, semi presidential system, constitution, party, civil society, governance, state

\section{Introduction}

"There is one thing we already know about Guinea-Bissau's democracy: every day is a new (worst) day". Guinea-Bissau is an infamous country for its cyclical politico-social crisis that have undermined several attempts to establish the process of socio-economic development and sound government that serves the best interests of the country. It is an irritable moment in history of Guinea-Bissau. We have seen the growth of poverty and misery - all fed by anxiety and mistrust. Politicians advocating and promoting corruption, irresponsive decision-making, and poor government performance. The leaders are without accountability and transparency. They make themselves rich illegally and ignore the problems of the country. 
Guinea-Bissau's 20 years of democracy leaves a pile of shards: "corrupt and inefficient public service system, economy with poor credit ratings, record indebtedness, deplorable health and education systems, incompetent leadership at all levels". The politicians and public servants do not serve the interest of the state and neither the people, but themselves. These politicians do not represent the common people, but the corrupt and effrontery elite.

Throughout its history of nascent democracy, Guinea-Bissau underwent numerous cycles of political, economic and social crises with many reflections in its course of democratization process. These crises have been intense, very violent and enormously consequential. None of theses crises brought any benefits to the people and society. In contrast, the crisis served to put the country in situations of political uncertainty that have left many people anxious, angry and afraid. Guinea-Bissau's first 20 years of democracy did not constitute any good outcome in the country. The leaders have been disgracing and destroying the country, dividing the society and weakening the state to get rich even as poverty and inequality broaden. According to Iaia (2017), one of Guinea-Bissau's problems is the excessive control of power for selfish financial gains.

The onset of democracy has given rise to absolute poverty and corruption in public institutions. After 20 years of democracy Guinea-Bissau still has hundreds of thousands of children out of school system. Countless children are in the suburbs wallowing in poor sanitary conditions and exposed to pandemics. There is a high number of women who lose their lives at childbirth due poor medical facilities. As the result of lousy democracy, Guinea-Bissau has the majority of people living miserably poor. Thousands of them are suffering from hunger and dying from curable diseases. The country looks set to limp from slump to slump.

Since the era of the National Liberation Armed Struggle, the Bissau-Guinean people have witnessed the collective disgrace. Guinea-Bissau once was a respected country in world for its masterful and glorious achievements, but now the state failed to fulfill the most basic aspirations and designs that were the ideals of a free, independent, and prosperous Guinea-Bissau. The biggest problem of Guinea-Bissau is the lack of commitment of the main organs of sovereignty and top leaders which effectively hold political power. Political leaders are less sensible in the management of state affairs, they do not know the role of the state in serving the people and developing the society. The top leaders instead of serving the people, they serve their own family and close friends around them. The state of Guinea-Bissau has been mismanaged and manipulated by the narcissistic politicians, who are committed to corruption and lies (Iaia Ture, 2016).

Misrule and mismanagement became dominant in Guinea-Bissau's democratic era. The laws, the legislations, regulations that exists are awful. The best qualified people are excluded in the system because of committing to the principle of legality. Disastrously, the mediocrities are promoted because they are so desirable to preserve corrupt system. The concept and the real essence of democracy are inverted. Woefully, when a good leader emerges, the incumbent corrupt leaders conspire against the person. They use malignant methods to destroy any person of good sense. These mediocre individuals serve as a precious jewel to the 
system, they are the ideal tools/ingredients and easy to handle, they never care about moral authority, good societal values or norms.

Guinea-Bissau's democracy is in profound crisis. The country is experiencing a crucial moment of negative changes that affect its identity and jeopardize the future of its people. Political and human geography has changed, the political economy has been altered and social crises have become acute. With the advent of democracy, Guinea-Bissau became a stateless republic, a so-called democratic state without democracy, a state of law without basic rights of citizens and with a constitution derived from elitism and founded on the basis of supremacy, that is, the deflection of spirit of democracy. Keane (2009) contended that "the true cause of our present difficulties is that democracy slept through the making of a deep crisis."

The political transition from mono party to multi-party democracy in Guinea-Bissau was completed when the first presidential and parliamentary elections were held in 1994. At the time, everyone expected that with democracy everything would be rosy. The masses thought social and economic problems would be solved and they would have a better life. But the political transition process did not address effectively the two main issues: social inequality and political inequality. These inequalities go beyond the economic issue of the distribution of wealth and promotion of differentiated access to public goods. These inequalities exclude a significant portion of the population from the decision-making process on the public policies to be implemented.

\section{Formation of Political Parties within Democratization Process}

Guinea-Bissau gained its Independence from Portugal on September 24, 1973. After a long and violent war of national liberation struggle that lasted 11 years. The PAIGC (African Party for the Independence of Guinea and Cape Verde), former Liberation Movement defeated Portuguese colonial power and liberated Guinea-Bissau and Cape Verde. The PAIGC ruled Guinea-Bissau for 21 years under single party rule before the advent of the multi-party system. Within the party-state rule, the ideological orientation of single party system in the country were the terms unity, union, viva (live), comrade, as well as other expressions of unity and struggle. Expressions such as, "we united and we love our country", "my brother/sister", unity is our strength," etc., were part of the most used vocabularies in everyday communication among the Guineans. Everything was expressed in plurality like we/us, and ours.

The democratization process started in May 1991, when the party-state (PAIGC) regime led by President Nino Vieira decided to revise the 1984's Constitution, among other amendments. He eliminated Art. IV, which consecrated the PAIGC as "the leading political force of society and the State" and, adopted the Law on Political Parties and Freedom of the Press. In August 26, 1991, National Assembly approved the law on political parties, which allowed multi party system. According to the constitution of Guinea-Bissau "political parties are permanent citizens' organizations formed under the terms of the law, with the main objective of democratically participating in the political life of the country and competing with freedom and equality for the formation and expression of the political will of the people under the 
existing laws on the constitution" (Chat.1, Art.1. Law no. 4/91 of August 26). This law allows citizens to form political parties and fully participate in democratization process, to commit and promote democracy.

\section{Political Parties or Onion Peels}

The origins of the opposition parties to the party-state "PAIGC" regime can not be sought only in the period of democratic liberalization. It dates back to the first years after independence. It becomes stronger and stronger as the conditions of its emergence were accumulating by successive mistakes and deceptions. The intention of opposition was fulfilled after the abolition of Art. IV, and the adopted and approval of law on political parties.

The study of political parties seems to be like other scientific researches which lack consensual definitions among academic experts and researchers. Anthony Downs (1957) contended that "a political party is a team of men seeking to control the governing apparatus by gaining office in a duly constituted election". British politician Edmund Burke stated that "a political party, ideologically, is a body of men and women united on the basis of their shared political ideas so as to promote national interest. For Professor Giovanni Sartory, political party is any political group identified by an official label that presents at elections, and is capable of placing through election, candidates for public office (Sartory, 1976).

Between 1991 and 1993, there was the birth and proliferation of several party formations. Thirteen legalized parties contested during the first legislative (parliamentary) elections of 1994. Among these parties, there were only two parties, the National Liberation Front of Guinea (FLING) and the Guinea-Bissau Resistance - Ba-fata Movement (RGB-MB). These were not the result of splits or dissidents from the PAIGC or created by former militants or leaders of the party-state. The fragility of the political parties and the weakness of their leadership were visible since the beginning of democratization process, most parties also did not have an organized project for society that could inflate the political field allowing new development alternatives and make the path of democracy more difficult to be achieved. The weakness of opposition parties began when they failed to form a united front against the state party. According to Carlos Cardoso, the opposition was deeply divided throughout the transition process and even on the eve of elections. The existing opposition parties saw each other more as political rivals than political allies (Cardoso, 1995).

Initially, there was the idea of forming a democratic forum within the opposition parties with the intention of uniting against the ruling party - PAIGC - in order to defeat it in the first elections. This initiative, however, did not materialize due to the differences on who should take the leadership of the democratic forum. The major problem was how to converge the opposition parties and who should be leader of the democratic forum. Who was to lead who and who was to submit to whom? Cardoso (1995) stated that: "Democratic Forum succumbed to the secondary character of differences and the hegemonic ambitions of their leaders." Since the beginning of democratization process and throughout the last 20 years of democracy, only few parties may have achieved a true implementation of political bases (branches) in different parts of the country. 
In the last 20 years of democracy, Guinea-Bissau has experienced several hasty and tumultuous political transformations in a context marked by the proliferation of political parties. It is a fact that the constitution of various political formations in Guinea-Bissau since 1991 has also been characterized by conflicts of interest and various dissent. Lack of political vision, ideological principle, organized ideas and development perspective reinforcing the argument of the logic of the conflict in the recent history of the country. Guinea-Bissau has countless political parties and many of them are "nothing party or onion peels". The parties have nothing and everything is associated with nothing. Some are just Family party (wife-husband party or party of brothers). The data from the Supreme Court shows that Guinea-Bissau has legalized 38 parties (Lusa, June 14, 2016). What is a small country like Guinea-Bissau doing with 38 parties for an electorate of about 700,000 voters in a country with 1.8 million inhabitants? Most of parties have no programmes reflected on their own political ideology. Lars (2001) opined that, "it is not possible to distinguish between the political parties in Guinea-Bissau by studying their party programmes. The slogans of all the parties are almost identical. The programmes and other documents demonstrate very clearly that all the parties claim to stand for democracy, justice and human rights, as well as a market economy that is socially accountable."

Often, having a party in Guinea-Bissau does not mean that you have a unique idea identified with a certain political ideology or linked to some principles or values that you believe in. Or you have any programme to develop the country. Presumably, 98\% of the "political parties" are nothing parties, the parties haven't neither ideology nor political structure. They are "onion peels". The majority of the parties are necessarily formed to look for ways to earn a life and rise up in society. Today, it is clear that the political class has no agenda, and apparently, there is no attractive ideology, sometimes even the top leaders are not identified with any political values or principles. The main objective and the only one thing that connects them together is simply "seeking and seizing power to get rich" (Iaia, 2016).

\section{People's Participation}

Participation has an ample extent of definitions. Devas and Grant pointed out that, "citizen participation is about the ways in which citizens exercise influence and have control over the decisions that affect them" (Devas and Grant 2003). While Kelly (2001) defined participation as "a range of processes through which local communities are involved and play a role in issues which affect them. The extent to which power is shared in decision-making varies according to type of participation". Lane proposed that "meaningful participation of individuals and groups at all stages of the development process including that of initiating action" (Lane, 1995). Agarwal, as one of the supporters of theory of participation, asserted that "at its narrowest, participation is defined in terms of nominal membership and at it broadest in terms of a dynamic interactive process in which all stakeholders, even the most disadvantaged, have a voice and influence in decision-making' (Agarwal, 2001).

Participation has been seen as an opportunity to find solution for the burning issues (unemployment, inequality, healthcare, education, poverty). Then, participating in elections and enjoying the right to vote to choose the leaders to lead the country is one of the ways to 
choose freely. Many Guineans consider participation in elections as not only a right but also a responsibility. It is a way to involved in the decision-making process for social development. The people believe that democracy through elections to elect own leaders would bring the change and prosperity for the country.

The voters of Guinea-Bissau have always gone to the polls in a peaceful, calm and orderly, patriotic manner, and with great enthusiasm to elect their President and the 102 deputies for the National People's Assembly. According to the President of National Commission for Elections (CNE), Augusto Mendes, the voters have been flocking in droves to polling stations and the percentage of participation in most regions are always higher than $80 \%$ (DW, May 23, 2016; Lusa, May 23, 2016; O democrara, May 23, 2016). The people have always tried to fulfil their civic duty without startling, even in moments of great political tension. Since from the first elections held in the country in 1994 the people have always accomplished their commitment in exercising their democratic right. See table 1.

Table 1. The percentage of people's participation in different elections held in Guinea-Bissau

\begin{tabular}{llllll}
\hline Year & Type of elections & Registered voters & Voted & Abstention & \% \\
\hline $\mathbf{1 9 9 4}$ & General elections & 400.417 & 357.682 & 42,735 & $89,3 \%$ \\
$\mathbf{1 9 9 9}$ & General elections & 502,678 & 371.025 & 131,653 & 73,81 \\
$\mathbf{2 0 0 4}$ & Parliamentary & 156233 & 115853 & 40380 & ---- \\
$\mathbf{2 0 0 5}$ & Presidential & 538,472 & 471.843 & 66,843 & $87, \%$ \\
$\mathbf{2 0 0 8}$ & Parliamentary & 593,739 & 486,873 & 106,866 & $82 \%$ \\
$\mathbf{2 0 0 9}$ & Presidential & 593.765 & 356.340 & $39 \%$ & $61 \%$ \\
$\mathbf{2 0 1 2}$ & Presidential & ----- & ----- & ------- & ------- \\
$\mathbf{2 0 1 4}$ & General elections & 775,508 & 686,876 & 88,632 & $88,57 \%$ \\
\hline
\end{tabular}

Source: CNE - Gunea-Bissau (1994, 1999, 2004/5, 2008/9, 2012, 2014); EU Election Observation Mission to Guinea Bissau, 2005, 2008, 2009, 2014)

Table 1 shows the rate of people's participation in different elections held in the country, since the first and historic democratic elections held in 1994, until the last one held in 2014. The people have always been responding to the politicians' when they are called to vote. In contranst, the politicians make huge promises during campaigns about changing the country and improving the quality of life of the people. But when they indeed get elected into public office, everything becomes different, they (politicians) promise a lot and fulfill nothing.

\section{Participation VS Deception}

In order to be elected, politicians make a never-ending set of promises. The more promises they make, the more they deceive the masses. The politicians make voters believe that they will succeed in ending hunger. The politician who promises more gets elected. As a result, the art of lying has been allied to the art of electing. Guinea-Bissau political arena is full of mediocre politicians, who no longer bother to disguise themselves in the service of the people, even though they have been elected by the people. Political leaders forget that "the people do not vote for mere gratitude, rather the people vote for life improvement and vote for hope to build better a society. A Guinean medical doctor expressed his dissatisfection by stating that "the politicians are devils, today they say something and tomorrow they do something different from truth" (personal survey Interview, October 1, 2016). Obviously disappointed, a 
young lawyer (Leonardo Indi) said that "the politicians are heartless, they lie to get power and forget everything they promised the people in electoral campaigns and they do not solve anyone's problem" (personal survey Interview, September 28, 2016). The voters are very angry at politicians' depressing outcomes, while the social crisis is increasing and poverty speaks out.

Since the beginning of multiparty regime, Guinea-Bissau chose the semi-presidential system which was influenced by Portugal. But even after 20 years of democracy there still debate about Guinea-Bissau's semi-presidential system. Some believe that Guinea-Bissau semi-presidential system has characteristic of presidential system because power is concentrated on president, and no shared powers as a semi-presidential normally demands.

Semi-presidential system is the presence of both a popularly elected and powerful president and a parliamentary-dependent prime minister (Duverger, 1980). According with Elgie "semi- presidentialism is the situation where the constitution identifies both a directly elected president and a prime minister responsible to the legislature" (R. Elgie, 2007).

Guinea-Bissau's semi presidential system seems to be a mixed executive between the Presidential power and the Government power, but in reality there is no mixed executive. The executive is only "the Government", not the President. "The President is Head of the State" (Art. 69), while the Prime Minister is "Head of Government" (Art. 97). It is not the President that governs; it is the government that governs the country. Guinea-Bissau's semi presidential system is greatly influenced by the legacy of the single party system in which the commander-in-chief was everything, where the president was a "big boss" and exercises absolute power. And also the practice of the system is more presidential system in nature rather than pure semi presidential system itself.

The era of democracy has been marked by endless struggles for power among political leaders, principally, among the presidents and prime ministers. The politicians abandoned the most important concerns such as building a democratic state based on the rule of law with a view to developing the society. They have always promised a number of improvements but fail to follow through with their promises. On March 10, 2017, a civil society organization known as "The Movement of Conscious and Unhappy Citizens" organized a mass protest against the regime, the protesters sat on the street during an anti-government rally demanding the resignation of Guinea-Bissau's President, Jose Mario Vaz. The movement said that "the protest action aimed to raise public awareness on the need to say "enough" to the President". The movement accused the president of lying to the people and being the man responsible for the political crisis (Abola; Ditadura do consenso; RTP; March 10, 2017).

The Guinean society is divided between those who "tread" and those who are "trodden" placing equal people on different planes. The best equipped of means are inexorably driving the fate of their fellow citizens who have fewer resources. With democracy we live in a permanent crisis of legitimacy of the political model, which does not correspond to the needs and the expectation of the people. The hope of illicit self enrichment and the certainty of impunity are greater than the fear of being caught, which is why it is worth risking. The different presidents had shown failing commitment to the preservation of the constitutional 
order and respect to separation of power. On May $28^{\text {th }}, 2016$, Leader of ruling party, Domingos Simoes Pereira, reiterated bluntly that President Jose Mario Vaz violated the Constitution by naming personal friend, Baciro Dja as prime minister, without having listened to parties with seats in parliament or the Council of State (RFI, May 28, 2016), leaving out the winning party of the last parliamentary elections, whom hath have the right to form the government according to the constitution (art. $68(\mathrm{~g})$ ).

The 23 years (1994 to 2017) of democracy were distinctive by the inconsistencies that tarnished and even still stain the democratic exercise in Guinea-Bissau. The main rights that are innate to human kind as the right to freedom, freedom of expression, right to life are still to be improved. According to the President of National People Assembly, Cipriano Cassama, "several constitutional uprisings that occurred did not produce positive effects but instead complicated the normal course of democratic process and the country's relationship with the partners and the International Community" (Intelectual Balantas Na Diaspora; ANG, RTP; Oct. 6, 2014). While Prime minster, Domingos Simoes Pereira, stated that the last twenty years of Guinea-Bissau were marked by the advent of democracy but always postponed by cyclical periods of instability and violence that have not allowed society and the populations to benefit from a conducive environment to an experience and coexistence that is desirous of harmony (RFI; ANG, RTP; Oct. 6, 2014).

The two decades of democracy were marked by successive governmental upsets, constant and unnecessary changes in leadership, which provoked the fragility and increased corruption in the state institutions. Within democratic course (1994 to 2018) Guinea-Bissau has had ten (10) presidents and twenty-two (22) prime ministers. An average of 2.3 years for each president and 1.09 year for the prime ministers. See table 2 below.

Table 2. Number of presidents and prime ministers served Guinea-Bissau from 1994 to 2018

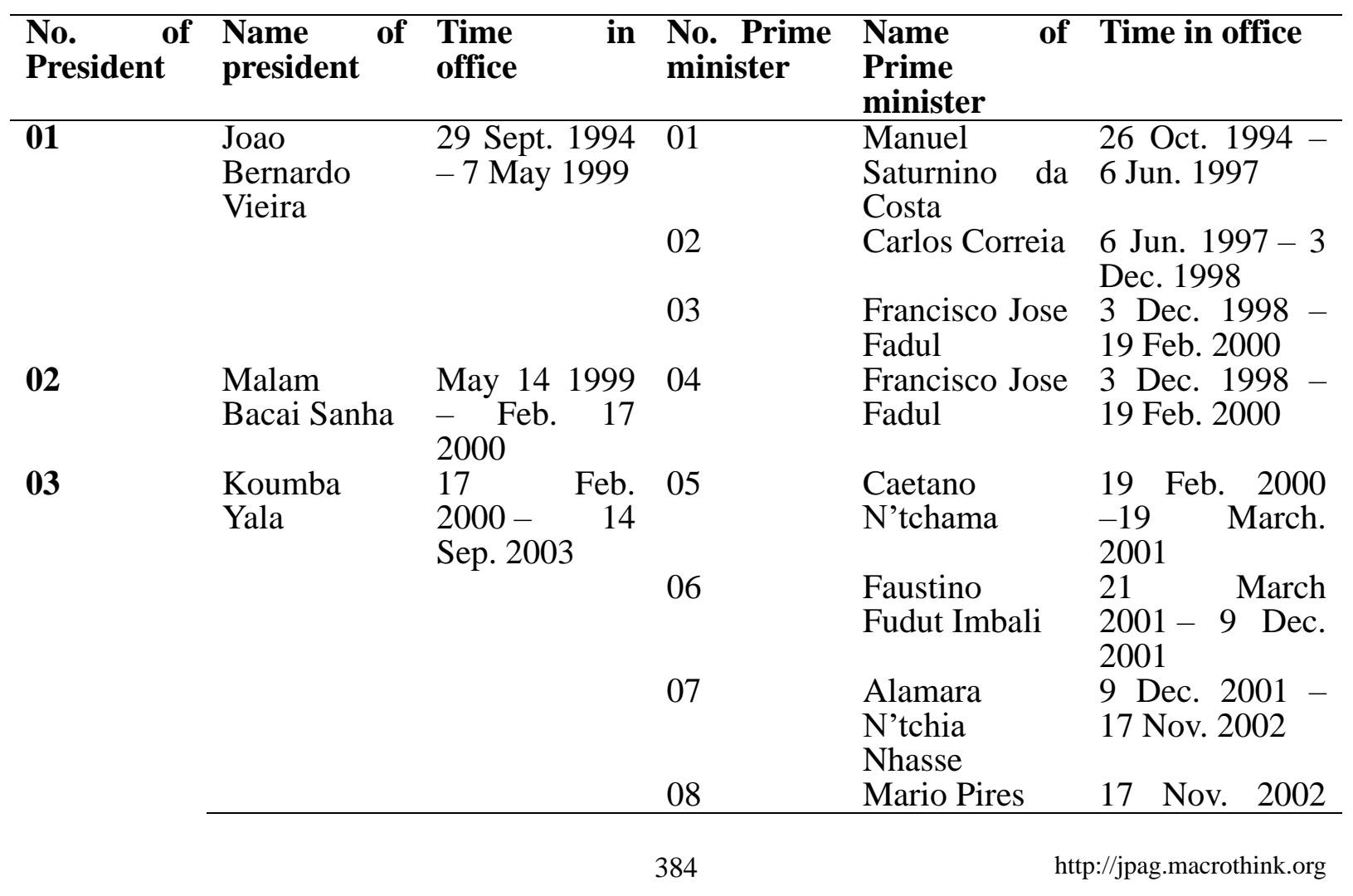




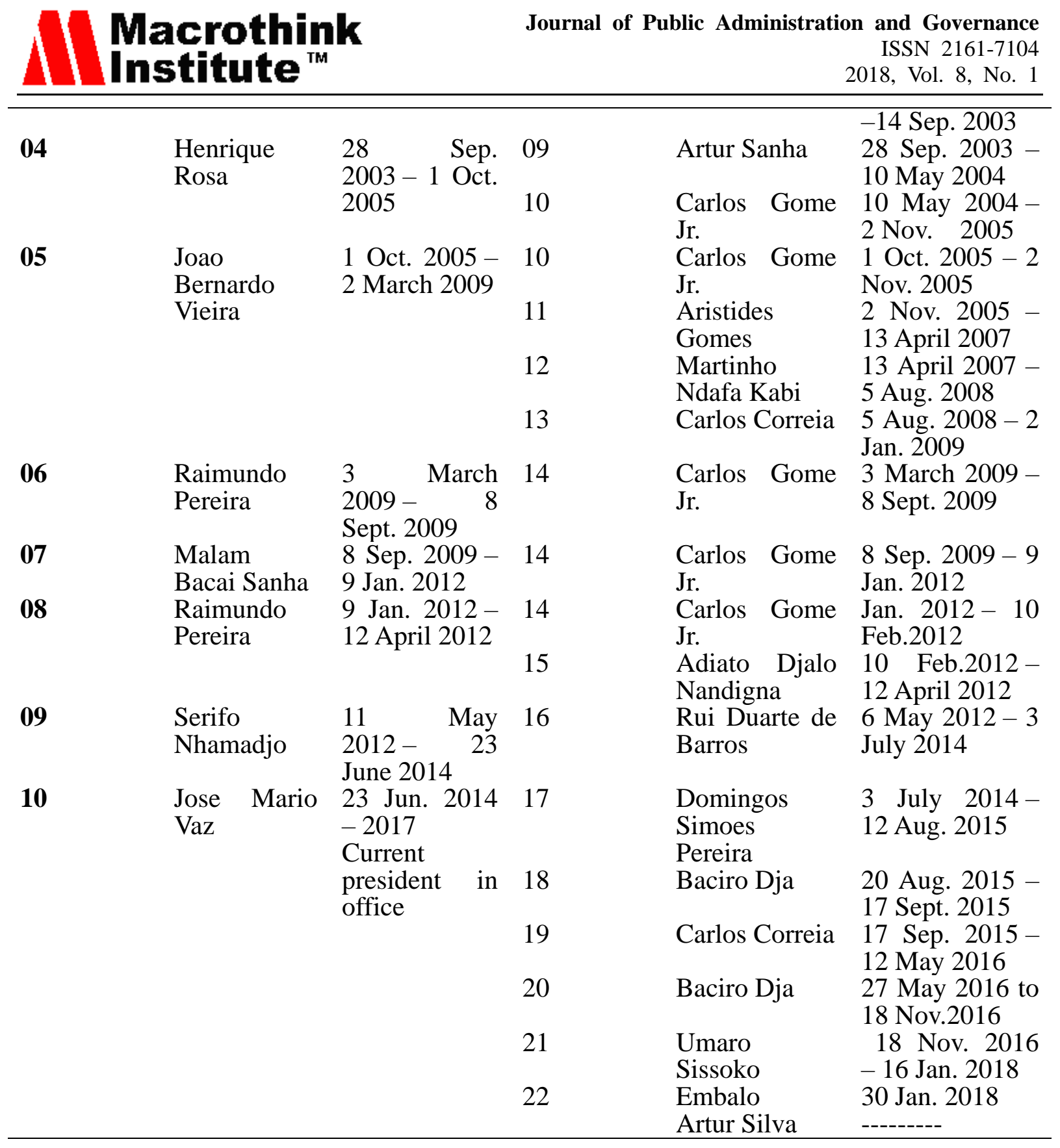

Source: Author

\section{Constitutional Power VS Transgression of Power}

Guinea-Bissau's semi-presidential system has been suffering from the scrapes of parochialism and misapplication of the concept. The President has ample powers regarding the dismissal of the cabinet whenever he/she chooses to. This constitutional design clearly undermines the authority of the constitutional mandate of the Prime Minister as Head of Government. The overlapping of powers in the leadership of the government shows some ambiguity in Guinea-Bissau's Constitution. According to the constitution, the President appoints a prime minister after auscultating parties with parliamentary seat and taking into account electoral results (winning party of parliamentary elections should form the cabinet and president announce the cabinet) (art. 68 (g)); the President appoints and dismisses ministers under proposal of prime minister (art. 68 (i)); Swear in the Prime Minister (art. 68 (h)); Chair the Council of Ministers when he/she wants (art. 68 (m)); appoints and dismiss 
Army chief of staff under proposal of government (art. 68 (o)); appoints and dismisses the Prosecutor-General, after hearing the government (art. 68. (p)); appoints and dismisses the ambassadors after hearing the Government (art. 68 (q)). The president still has power to dissolve the National People's Assembly (art. 69 (a); and dismiss the Government, in accordance with art. 104 (2). The constitution centralized substantial powers on the presidential power. Nevertheless, the presidents are not satisfied with constitutional power, oftentimes, the presidents divert the legal principle "by opting for an appointment on the sidelines of the will of the competent body to nominate candidate for the post of Prime Minister, replacing the winning party of the elections," which is absolutely unconstitutional and transgression of power.

Forming a cabinet is the prerogative of the party that wins the parliamentary elections. It enjoys the right to form the government and to govern the country according to its electoral programme. The presidential power is merely formal and its power is strong only on paper. The president cannot deny any cabinet appointment proposed by the Prime Minister and the president has simply to announce the cabinet. By contrast, the different Presidents have always abused the cabinet appointment procedures by simply ignoring all legal acts and implement their personal agenda. The successive Presidents of Guinea-Bissau have always managed the state issues in favour of their private businesses. Opposition leader, president of the Party for National Unity (PUN), Idrissa Djalo, accused the president Jose Mario Vaz and his cronies of being a robber of the people, and he associated them with corruption of the state apparatus and in the private sector (Nota Na Banca, March 3, 2017).

The democratic experience in Guinea-Bissau is still very bounded and anemic. Recently, the country found the duality of governance programme (Mon Na Lama and Terra Ranka). On one side, you have a programme (Mon Na Lama) from the President who is trying to implement his own agenda. On the other side, you have a government programme (Terra Ranka). But according to the law of Guinea-Bissau only the government should have a programme accompanied by the state budget which should be submitted to the National People's Assembly for its approval (art. $84(\mathrm{c}, \mathrm{g})$ ) before its implementation. The government is the only legal entity with the right to have governance programmes because the government is politically accountable to the President and to the National People's Assembly (art. 103). In a semi presidential system, the President cannot and should not have personal/private programmes. The President's programme is the constitution. In this political system, the President must be, in essence, a referee of political game and not a player within political parties (Iaia, 2016).

\section{Role of Media in Democratization Process}

The evolution of democracy - and the very democratic state as a whole - over time, is reflective result of the sum of many contributions of the media. The media provides social, public and essential service to society, spreading knowledge and making the unattainable, often, achievable.

Implementing democracy needs the effective participation of majority of citizens in democratization process. Gorgeously, the media have to keep citizens engaging in the matter 
of public governance by informing, educating and sensitizing the community. In Guinea-Bissau's toddler democracy, radio has become the golden choice, as it is cheaper and handier. The blogs also, are playing important role, but they are still very less accessible to the majority of the people. Newspapers and television channels are only accessible by few people, many of them are elites.

Unfortunately, the media in Guinea-Bissau have been facing several problems such as: (i) lack of professionals and qualified journalists; (ii) lack of the code of ethics of journalism; (iii) lack of good working condition (poor salary, research tools and equipment); (iv) Financial dependence. Guinea-Bissau's media have frequently fanned the fires of disharmony by taking sides, bolstering prejudices, intricacy the facts and peddling falsity. The media is poorly performing, there are no well disciplined rules to direct the professionals of the area and journalist class lacks of prepared professionals. As we have seen many journalists, radios, TV's and blogs have been used by some interest groups to influence, manipulate information to attack political rivals. The President of the Journalists Order of Guinea-Bissau lamented the negative role that the press is playing in the country ( $O$ democrata, March 12, 2017). Mamadu Cande, President of Union of Journalists, said that "the financial difficulties in Guinea-Bissau are causing some media to "sell" to the candidates in the elections and to be manipulated for financial gains (Conosaba, April 27, 2014)

The media is supposed to be the guardian of democracy and promoting inclusiveness in society, inciting good governance, accountable and transparent governments. In contrast, the media are playing anti-democratic roles, calling for violence and divisiveness rather than build up the society. Instead of promoting democracy, they are contributing to democratic blight and promoting corruption. Some media always look for their usual comfort zone where they always have to earn money to live by selling information. According with Sheila Coronel "the media have sometimes fanned the flames of discord by taking sides, reinforcing prejudices, muddling the facts and peddling half-truths (Sheila S. Coronel, 2003). Many blogs have been created for exchange information for financial gains. One blogger who published his video on YouTube, said that "he associated with some group of politicians to overthrow democratically elected government by slandering political rivals and misinforming the public and placing the other group in power. He demanded his urgent appointment to public office or for his mother to a government post as the result of his work after they succeed in overthrowing the elected government and seize power (Guinendade; YouTube, January 14, 2017).

\section{Politicized Media}

The media is deeply politicized in Guinea-Bissau. The media function to deform democracy. Guinea-Bissau has had very concrete experiences in the history of democracy of the country, for example, some radios in the country that decided to support some political parties with their candidates for the general elections, practically elected these candidates as the next president or as next party to form the Government before elections. Obviously, it is not the role of the media to replace the action of political parties. This is an improper role and usurp this function, which is a function of society, is a great malformation of the democratic process. 
2014 EU Electoral Mission to Guinea-Bissau reported that "the media had to compromise their independence in exchange for financial survival (European Union Electoral Report, 2014). "Peace journalism," which is being promoted by various NGOs, endeavours to promote reconciliation through careful reportage that gives voice to all sides of a conflict and resists explanation for violence in terms of innate enmities (S. Coronel, 2003).

State owned media commencing by radio, television and newspapers are all controlled by a party that governs the country. These bodies are barred from doing any journalistic coverage for other political rivals or any other non ally partners. A Guinean journalist (Chief editor, Aliu Cande) of the National Broadcasting of Guinea-Bissau (RDN) was fired from his post for having passed news of a political leader that the government did not want. The same thing happened in National Television of Guinea-Bissau (TGB) were the Chief editor was also dismissed for having passed the news of a political party who was opposing the government. Opposition leader, Nuno Gomes Nabian criticized the state media attitude for being partial and suggested that the National Television of Guinea-Bissau (TGB) should be renamed to TV-PRS to remove a name which is linked with the state media and naming it with a party name (Ditaduradoconsenso, Novemeber 02, 2016).

\section{Role of Civil Society Organization}

The term "civil society" is very complex and has broad meaning. Civil society refers to the wide array of non-governmental and non-profit organization that have a presence in public life, expressing the interest and values of their members or others, based on ethical, cultural, political, scientific, religious or philanthropic considerations (World Bank, 2010). Michael Edwards $(2015,2009)$ defined civil society as "simultaneously a goal to aim for, a means to achieve it and a framework for engaging with each other about ends and means." For Scholte (2011) "civil society can be understood to be a political space where voluntary associations deliberately seek to shape the rules that govern aspects of social life". In the1991, with the onset of democratization in Guinea-Bissau, we witnessed the creation and proliferation of various associative formations, partisans, trade unions and socio-political formations, which today shaped so called "civil society movement", linking the private sector to support practices and shared assistance. Such opening was facilitated by the amendment of the constitution, which allowed political pluralism, freedom of expression and press.

The fragility and, in some cases, the absence of the state at all levels, these state fractures have a huge impact on the communities. Civil societies, particularly the religious associations and NGO's have a decisive role to play in the poorest communities, as well as in the process of consolidating democracy and promoting development. Although Guinea-Bissau has numerous of non-profit organizations with social nature which are not subject to direct state control, with a view to achieving social or public purposes, which are receiving funds every year. But due the weakness of the state to control the funds received by NGO's and the ineffectiveness and inefficiency of NGO's on the ground in implementing project grants, the third sector still does not produce enough result as expected. 


\section{Conclusion}

The constant political turbulence in Guinea-Bissau is delaying and postponing socio-economic development and increase penury. The poverty has affected the people for decades. Leaders have done nothing to solve basic problems and create conditions for proper democracy. This is the time for all Guineans put aside personal or parallel agendas. It is essential that all Guineans work together to overcome this enormous challenge. The timing is grave and dramatic enough. Democracy has divided rather than united Bissau-Guineans and the leaders are ignoring primary democratic values and the rights of the citizenship.

Guinea-Bissau's traditional culture, moral and/or ethical values are cruelly dethroned by the politicians. Corruption gained ground as it infiltrating at all levels of the state apparatus in Guinea-Bissau including in both private and third sectors within planted scheme, as illicit enrichment became fashion among political elites. Unexpectedly, the country has been producing skilled corrupts (elites) in recent years, popularizing immorality and discrediting peerless history of Guinea-Bissau. The elites whom, for decades, have dealt with themselves (solved their own problems) and did not solve the problems of Guinea-Bissau and despising the poor people in the communities and neighborhoods. Now all Bissau-Guineans feel the rift rows of a fractured country.

There is need for good leadership in Guinea-Bissau to change the country's direction due to the fact that nothing can protract as before. The country, the people, the society must be treated with the "sensibility" and "it is necessary to unite the people and win back the country". As the role of democracy is to construct a more equitable and fair society, to build a safe country, strong and prosperous society.

\section{Recommendations}

1. Government should urgently, undertake a deep and serious political and constitutional reform. And create the Constitutional Court with the powers of supervisory of constitutionality. Making serious advances in the reform of judiciary and in dealing with corruption acts and promote rule of law. Creating new legislation that politicians are not allowed to committed to self-interest and economic power;

2. The political leaders should endeavour to embolden democratic core values such as participation, inclusiveness, freedoms of the press and respect for human rights;

3. Government should promote competence, anti-corruption and patriotism. harmonize development to value the potentials the country has;

4. Political leaders and elites should lead the country with wisdom. A leader ought to be someone who is ready to fight tirelessly and positively contribute to building and developing society;

5. Government should carry out decentralization of administrative power from central to local administration and respect separation of power, especially, separating justice system from political power and politics from administration. 


\section{References}

Agarwal. (2001): Participatory Exclusions, Community Forestry, and Gender: An Analysis for South Asia and a Conceptual Framework. World Development, 29, 1623-1648. https://doi.org/10.1016/S0305-750X(01)00066-3

Anthony, D. (1957). An Economic Theory of Democracy. Publisher New York: Harper and Brothers. Collection print disabled; inlibrary; internet archive books; China.

Carlos, C. (1995). Os Desafios da Transição política na Guiné-Bissau. Instituto Nacional de Estudos e Pesquisa, 1995.

Christoph, K. (2011). Construindo a nacao na Africa pos-colonial: o exemplo de Guine-Bissau.

Constitution of Republic of Guinea-Bissau.

Devas, \& Grant. (2003). Local government decision-making - citizen participation and local accountability: some evidence from Kenya and Uganda

Edwards, M. (2009). Civil Society. Polity Press: United Kingdom, 2009.

Elgie, R. (2004). Semi-presidentialism: Concepts, Consequences and Contesting Explanations.

EU Election Observation Mission Guinea-Bissau 2005 - Final Report on the Presidential Elections.

EU Election Observation Mission Guinea-Bissau 2009 - Final Report on the Presidential Elections

EU Election Observation Mission Guinea-Bissau 2014 - Final Report on the Presidential Elections.

(Online)

Available https://eeas.europa.eu/headquarters/headquarters-homepage/23911/eu-election-observation-m ission-guinea-bissau-2014_en

Giovanni, S. (1976). Parties and Party Systems: A Framework for Analysis of Parties and Party Systems ·Publisher, Cambridge University Press, 1(1). ISBN, 0521212383, 9780521212380 .

Jan, A. S. (2011). What is Civil Society (1)?

John, K. (2009). Democracy failure - The root of the global economic crisis is political. WZB-Mitteilungen, (Heft 124 Juni 2009), 6-8.

Lane. (1995). Non-governmental organisations and participatory development: the concept in theory versus the concept in practice. In 'Power and Participatory Development'. https://doi.org/10.3362/9781780445649.016

Lars, R. (2001): On Democracy's Sustainability - Transition in Guinea-Bissau. Edição 4 de Sida studies, ISSN 1404-9562 Volume 4 de Sida studies: 2001 


\section{Macrothink}

Journal of Public Administration and Governance ISSN 2161-7104 2018, Vol. 8, No. 1

Lei-quadro dos partidos politcos - lei no.04/91 de 26 de Agosto - artigo 56 da Constituição da Republica da Guine-Bissau http://www.odemocratagb.com/cipriano-cassama-guine-bissau-e-conhecido-pelas-suas-ciclic as-crises-politicas-e-sociais/

Maurice, D. (1980). Semi-presidential - Duverger's Concept - A new Political System Model. European Journal of Political Research, https://onlinelibrary.wiley.com/doi/abs/10.1111/j.1475-6765.1980.tb00569.x

Nelson, N., \& Wright, S. (1995). Participation and power. In 'Power and participatory development'. https://doi.org/10.3362/9781780445649.001

Recenseamento, B. G. B. (2010). Ministerio da Funcao Publica e de Modernizacao do Estado.

Robert, E. (2007). Varieties of Semi-Presidentialism and Their Impact on Nascent Democracies. Taiwan Journal of Democracy, 3(2), 53-71.

Sheila, S. C. (2013). The Role of the Media in Deepening Democracy. https://anyflip.com/mkas/oeno

Ture, I. (2016). Política, Caráter e Lideraça: Tudo em torno da Verdade, (Online) Availeble: http://tchogue.blogspot.com/2016/03/guine-bissau-politica-carater-e.html

Ture, I. (2017). Public Administration Reform and Decentralization Policy in Guinea- Bissau. International Journal of Education and Research, 5(5). www.ijern.com

Ture, I. (2017). The Challenges of Democratization and Good Governance in Guinea-Bissau. Journal of Public Administration and Governance, $7(2)$. https://doi.org/10.5296/jpag.v7i2.11261

Voz di Paz. (2010). The root of conflict in Guinea-Bissau: the voice of the people. Published by: Voz di Paz / Interpeace. (Online) available: http://www.interpeace.org/wp-content/uploads/2010/08/2010_GB_Interpeace_Voz_Di_Paz_ The_Voice_Of_The_People_EN.pd

While, K. (2001). Community Participation

World Bank. (2010). Adopting the World Bank's definition of Civil Society organization. http://go.worldbank.org/4CE7W046K0

\section{Copyright Disclaimer}

Copyright for this article is retained by the author(s), with first publication rights granted to the journal.

This is an open-access article distributed under the terms and conditions of the Creative Commons Attribution license (http://creativecommons.org/licenses/by/4.0/). 